\title{
STRATEGIC TRADE ANALYSIS OF U.S. AND CHINESE APPLE JUICE MARKET
}

\author{
JEFF LUCKSTEAD* \\ Assistant Professor, Agricultural Economics and Agribusiness, University of Arkansas, Fayetteville, Arkansas. \\ STEPHEN DEVADOSS** AND MAHALINGAM DHAMODHARAN** \\ Professor and Graduate Student, Department of Agricultural Economics, University of Idaho, Moscow, Idaho.
}

\begin{abstract}
Because of high competition from Chinese apple juice processors, the United States imposed an antidumping duty on apple juice imports from China to protect the domestic processors. This trade policy benefited U.S. processors but negatively impacted Chinese processors as well as consumers in the United States. Because of the economic reforms, foreign direct investment, and technological spillover, Chinese apple processors have increased their productivity. Under oligopolistic competition with endogenous firm entry and exit, this article analyzes how the changes in U.S. tariff policy and Chinese productivity impact the market structure in the United States and China, as well as prices, quantities, and U.S. and Chinese welfare. Trade liberalization and an increase in Chinese productivity help U.S. consumers and Chinese processors. However, U.S. tariff removal adversely affects U.S. apple juice processors.
\end{abstract}

Keywords. apple juice, oligopolistic competition, productivity, trade policies

JEL Classifications: L13, F12, F13

\section{Introduction}

Although the U.S. apple juice supply has been declining for more than a decade, the Chinese apple juice industry has experienced rapid growth since the late 1990s due to several factors. In the early 1980s, the Chinese government promoted apple production in the underdeveloped highlands of the Loess plateau in the northwest and the highlands of the southwest to improve the livelihood of local farmers. The government provided subsidies for inputs such as apple saplings, fertilizer, and pesticides and loans to augment apple production (ZaiLong, 1999). Due to a favorable climate, high yields, and government support,

\footnotetext{
*Email: jluckste@uark.edu

**Email: devadoss@uidaho.edu

***Email: dham2854@vandals.uidaho.edu
}

We appreciate the comments of the anonymous reviewers and the coeditor Krishna Paudel. This work was supported by the U.S. Department of Agriculture, National Institute of Food and Agriculture, Hatch project BDH508. 


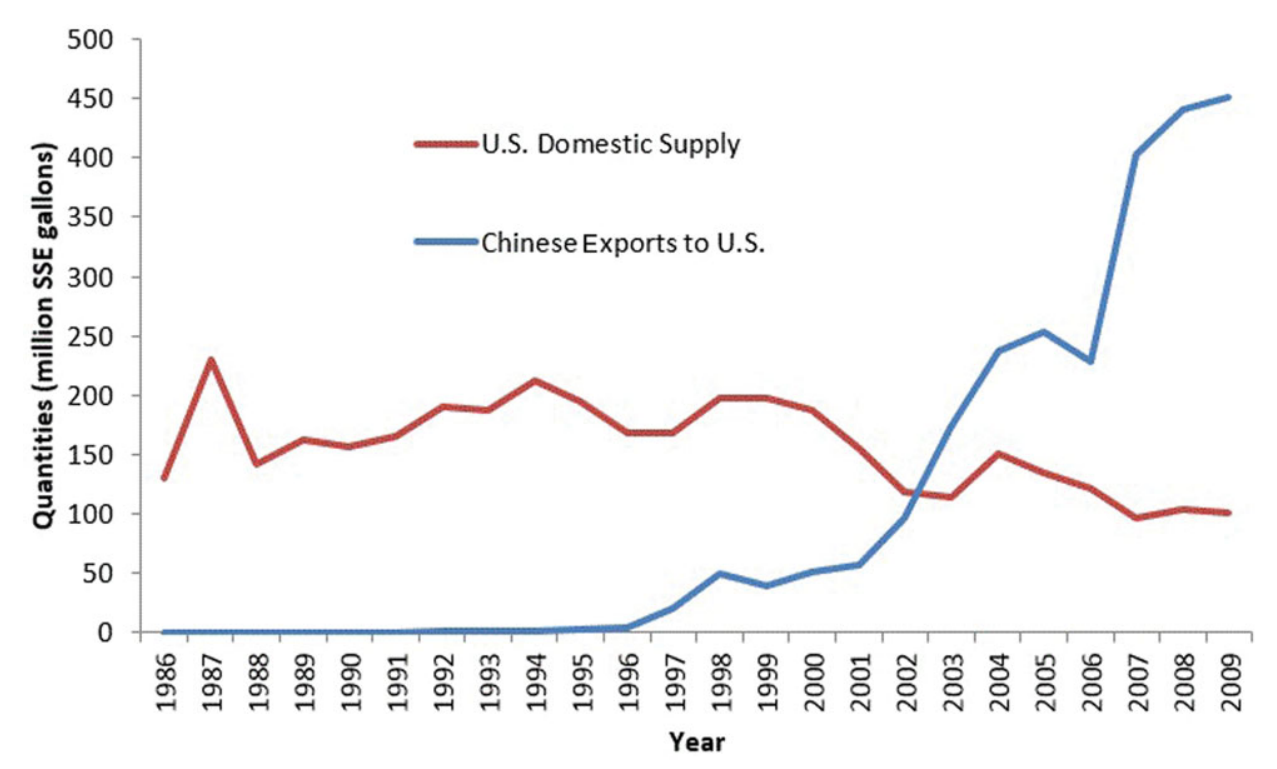

Figure 1.

apple acreage and production have expanded by 4.2 and 7.5 times, respectively, in the last two decades. As a result, apple supply outpaced domestic demand. In 1990, to alleviate the excess apple supply, the Chinese government encouraged investment in the apple processing industry. Since 1992, through investment of multinational firms and the Chinese government, the industry rapidly expanded apple juice production, and given the very low domestic consumption of juice, the government aggressively promoted exports. Currently, there are five major apple juice processors who control $72 \%$ of the total Chinese apple juice exports (Gale, Huang, and Gu, 2010). Due to cheaper labor and apples and conducive government policies, the Chinese share of the world apple juice market has increased from $0 \%$ in 1991 to $49 \%$ in 2009 . This led to a geographic shift in the concentration of the apple juice industry.

China has become the largest producer of apple juice, followed by the United States and Poland. With low domestic demand, Chinese apple juice processors export more than $90 \%$ of their production. China exported $40 \%$ of its total exports to the United States and 20\% to the European Union (EU) during 20072009 (Gale, Huang, and Gu, 2010). The United States also exports 33 million single strength equivalent (SSE) gallons to countries such as Canada, South Korea, and Japan (United Nations, 2014).

The United States started importing more from China because of the low Chinese juice price, which displaced imports from other countries such as Chile, Argentina, Mexico, and the EU. This has also led to a $47 \%$ decline in U.S. production since 1992 (see Figure 1). Consumption in the United States has 
increased from 350 million SSE gallons in 1986 to approximately 667 million SSE gallons in 2009. Consequently, the share of U.S. production in U.S. consumption declined from $37 \%$ in 1986 to $15 \%$ in 2009 . With consolidation of the industry as a result of increased competition and market saturation, only five major apple juice processors are operating in the United States (Apple Processors Association, 2014).

Cheaper imports and intense competition from Chinese exporters have put downward pressure on U.S. apple juice production, as shown in Figure 1. Specifically, Chinese apple juice exports to the United States increased from 20.71 million SSE gallons in 1997 to 451.35 million SSE gallons in 2009 . During this period, U.S. apple juice production steadily declined from 168.6 million SSE gallons to 100.3 million SSE gallons, affecting the profitability of both processors and apple growers. This prompted the U.S. government to impose an antidumping duty of 4.91 cents per SSE gallon in 1999 (World Trade Organization [WTO], 2014). However, imports from China continued to increase, contributing about two-thirds of total supply during the period 20072009.

Furthermore, the U.S. apple juice industry has been dominated by a small number of processors in both the United Sates and China. This concentration has likely led to oligopolistic competition in the U.S. apple juice industry among U.S. and Chinese processors.

Past studies have analyzed the U.S. and Chinese apple juice industry and trade under the assumption of perfect competition. For example, van Voorthuizen et al. (2001) analyzed the impact of the U.S. antidumping duty on Chinese apple juice on Washington state apple juice processors' revenues. They also estimated the demand for apple juice and intermediate input demand for apples. Rowles (2001) studied the U.S. processed apple markets and found that growers and processors face numerous challenges owing to changing market conditions. Rowles also concluded that only low-cost and productive firms will survive in the industry and less competitive firms will exit the industry. Fonsah and Muhammad (2008) analyzed the demand for imported apple juice in the United States and concluded that U.S. imports from Argentina, Chile, and the rest of the world were highly sensitive to Chinese apple juice prices. Similarly, Chinese exports to the United States were impacted by prices in Argentina, Chile, and the rest of the world. However, the responsiveness of U.S. imports from China to apple juice prices in these countries was relatively smaller than the responsiveness of imports from these countries to the Chinese price. Mekonnen and Fonsah (2011) estimated the U.S. import demand for apple juice using the restricted source differentiated almost ideal demand system model and found that U.S. demand for apple juice from China is inelastic and the expenditure elasticity is relatively high.

Devadoss, Ridley, and Sridharan (2012) constructed a spatial equilibrium model of world apple and apple juice markets to quantify the effects of tariff removal on these markets. Their results showed that trade liberalization had a 
considerably higher impact on the apple trade than the juice trade. They also found that exporting countries such as the United States, Poland, and China and importing countries such as India and Russia gain from this trade liberalization. Luckstead, Devadoss, and Mittelhammer (2014b) utilized new trade theory (NTT) and new empirical industrial organization methods to examine the degree of market power of U.S. and Chinese apple traders in Association of Southeast Asian Nations (ASEAN) markets under differentiated products. The results of their simulation analysis show that the ASEAN-Chinese free-trade agreement adversely impacts U.S. exports to ASEAN countries.

The current study advances the literature on the apple juice industry by analyzing the imperfect competition among U.S. and Chinese apple juice processors, examining the impact of trade policies and productivity changes on the apple juice markets, and endogenizing the market structure through endogenous firm entry and exit.

The objectives of this study are to (1) construct a strategic trade model of U.S. and Chinese apple juice industries; (2) theoretically examine the effects of U.S. tariff reduction and Chinese productivity increases on the apple juice markets in the United States and China; and (3) simulate the effect of exogenous changes in U.S. tariffs and an increase in Chinese apple juice productivity on prices, trade, and welfare in the United States and China.

\section{Theoretical Model and Analysis}

NTT purports that trade between countries having similar endowments and technology takes place because of economies of scale, distorted market structure, and differentiated goods (Krugman, 1992). For instance, Krugman (1979) found that due to differences in economies of scale, distorted market structure exists. He also established that trade and gains from trade will occur between countries with similar tastes and preferences, technology, and factor endowments. Later studies (Brander and Krugman, 1983; Dixit and Norman, 1980; Helpman, 1981; Krugman, 1980) incorporated oligopolistic competition and monopolistic competition into trade models to analyze reciprocal dumping and intraindustry trade. Studies by Venables (1985) and Horstmann and Markusen (1986) showed that strategic trade models under free entry and exit generate results that are different from those of models with a fixed number of firms. This point is also highlighted by Markusen and Venables (1988). ${ }^{1}$ Thus, it is important to analyze the apple juice trade by accounting for changes in market structure by allowing endogenous entry and exit of firms.

\footnotetext{
${ }^{1}$ Lahiri and Ono (1998), Markusen and Stähler (2011), and Etro (2014) extend the literature by covering strategic trade and foreign direct investment with an endognous number of firms in the home and host country.
} 
Melitz (2003) showed that productivity differences among firms lead to trade, and highly productive firms engage more in trade. He also found that trade barriers buffer the less productive firms and elimination of such barriers results in welfare gain. Melitz and Ottaviano (2008) developed a monopolistic competition trade model with firm heterogeneity and endogenous market structure to analyze how market structure changes in different markets that are not perfectly integrated through trade. This led to development of new NTT, which emphasizes patterns of trade and welfare due to firm-level differences in productivity (Ayumu, 2010).

Few studies have examined imperfect competition under trade protection and expansionary policies in agricultural commodity markets. Luckstead, Devadoss, and Mittelhammer (2014a) analyzed imperfect competition between U.S. and Chinese apple exports to ASEAN using homogenous products and strategic trade theory. Luckstead, Devadoss, and Mittelhammer (2015) have also applied strategic trade theory to study the U.S. and Brazil orange juice markets.

We develop a strategic trade model with zero-profit conditions for U.S. and Chinese apple juice markets based on the market structure outlined in the previous section. The firm-level profit function of U.S. apple juice processors is given by

$$
\pi^{U S}=p^{U S}\left(Q^{U D}+Q^{C U}\right) q^{U D}+p^{R}\left(Q^{U R}\right) q^{U R}-C^{U}\left(q^{U D}+q^{U R} ; \omega^{U}\right)-f^{U},
$$

where $p^{U S}$ is the price of apple juice in the U.S. market, $p^{U S}\left(Q^{U D}+Q^{C U}\right)$ is the U.S. inverse demand function, $Q^{U D}$ is the quantity of apple juice sold by U.S. processors in the United States, $Q^{C U}$ is the quantity of apple juice sold by Chinese processors in the United States, $q^{U D}$ is the firm-level output, $p^{R}$ is the export price of U.S. apple juice, $p^{R}\left(Q^{U R}\right)$ is the inverse demand function for U.S. exports, $Q^{U R}$ is total U.S. exports, $q^{U R}$ is firm-level exports, $C^{U}\left(q^{U D}+q^{U R} ; \omega^{U}\right)$ is the variable cost function, $\omega^{U}$ is the productivity parameter associated with apple juice production, and $f^{U}$ is the fixed cost.

The Chinese firm-level profit function is given by

$$
\begin{aligned}
\pi^{C}= & \left(p^{U S}\left(Q^{U D}+Q^{C U}\right)-\tau^{U}\right) q^{C U}+\frac{p^{E}\left(Q^{C E}\right)}{\left(1+\tau^{E}\right)} q^{C E}-C^{C}\left(q^{C U}+q^{C E} ; \omega^{C}\right) \\
& -t^{U} q^{C U}-t^{E} q^{E}-f^{C},
\end{aligned}
$$

where $\tau^{U}$ is the specific tariff imposed by the United States, $q^{C U}$ is the firm-level output sold in the United States, $p^{E}$ is the price of Chinese apple juice exports to the EU, $p^{E}\left(Q^{C E}\right)$ is the EU inverse demand function for Chinese apple juice, $q^{C E}$ is the firm-level output sold by Chinese processors in the $\mathrm{EU}, C^{C}\left(q^{C U}+q^{C E} ; \omega^{C}\right)$ is the variable cost function, $\omega^{C}$ is the firm-level productivity parameter in apple juice production, $t^{U}$ is the transport cost of shipments from China to the United 
States, $t^{E}$ is the transport cost of shipments from China to the EU, and $f^{C}$ is the fixed cost.

We obtain the first-order conditions by differentiating the profit functions (equation 1) with respect to $q^{U D}$ and $q^{U R}$ and (equation 2) with respect to $q^{C U}$ and $q^{C E}$ :

$$
\begin{aligned}
& \pi_{q^{U D}}^{U S}=q^{U D} \frac{\partial p^{U S}\left(Q^{U D}+Q^{C U}\right)}{\partial\left(Q^{U D}+Q^{C U}\right)}+p^{U S}\left(Q^{U D}+Q^{C U}\right)-\frac{\partial C^{U}(\cdot)}{\partial q^{U D}}=0 \\
& \pi_{q^{U R}}^{U S}=q^{U R} \frac{\partial p^{R}\left(Q^{U R}\right) q^{U R}}{\partial\left(Q^{U R}\right)} \frac{\partial\left(Q^{U R}\right)}{\partial q^{U R}}+p^{R}\left(Q^{U R}\right)-\frac{\partial C^{U}(\cdot)}{\partial q^{U R}}=0 \\
& \pi_{q^{C U}}^{C}=q^{C U} \frac{\partial p^{U S}\left(Q^{U D}+Q^{C U}\right)}{\partial\left(Q^{U D}+Q^{C U}\right)}+\left(p^{U S}\left(Q^{U D}+Q^{C U}\right)-\tau^{U}\right)-\frac{\partial C^{C}(\cdot)}{\partial q^{C U}}-t^{U}=0 \\
& \pi_{q^{C E}}^{C}=\frac{1}{\left(1+\tau^{E}\right)}\left(q^{C E} \frac{\partial p^{E}\left(Q^{C E}\right)}{\partial Q^{C E}}+p^{E}\left(Q^{C E}\right)\right)-\frac{\partial C^{C}(\cdot)}{\partial q^{C E}}-t^{E}=0 . \\
& \pi^{O U S}=p^{U S}\left(N^{U} q^{U D}+N^{C} q^{C U}\right) q^{U D}+p^{R}\left(N^{U} q^{U R}\right) q^{U R}-C^{U}(\cdot)-f^{U}=0 \\
& \pi^{O C}=\left(p^{U S}\left(N^{U} q^{U D}+N^{C} q^{C U}\right)-\tau^{U}\right) q^{C U}+\frac{p^{E}\left(N^{C} q^{C E}\right)}{\left(1+\tau^{E}\right)} q^{C E}-C^{C}(\cdot) \\
& -t^{U} q^{C U}-t^{E} q^{C E}-f^{C}=0 .
\end{aligned}
$$

Because the demand functions are downward sloping and the cost function is convex, the reaction functions will yield a solution because the profit functions are globally concave implying the second-order conditions for a maximum are satisfied. With specific functional forms for demand and cost functions, we can solve equations (3) to (8) simultaneously for six endogenous variables: $q^{U D}, q^{U R}$, $q^{C U}, q^{C E}, N^{U}$, and $N^{C}$.

\subsection{Comparative Statics}

In this section, we analyze the impact of a reduction in the U.S. tariff $\left(\tau^{U}\right)$ and changes in productivities (i.e., changes in $\omega^{C}$ relative to $\omega^{U}$ ) on quantities and number of firms. The general functional forms used in the previous section 
do not lend themselves to comparative static analytical solutions. However, we can ascertain the sign of the comparative statics using linear demand and cost functions that are commonly found in the literature (Markusen and Venables, 1988). These solutions are too long to report, and thus we provide only the interpretation of the comparative static results.

In response to U.S. tariff reduction, China will export more apple juice to the United States $\left(\frac{d q^{C U}}{d \tau^{U}}<0\right)$, leading to lower U.S. price and firm-level profits. As a result, U.S. firm-level quantity will decline $\left(\frac{d q^{U D}}{d \tau^{U}}>0\right)$, but it will export more $\left(\frac{d q^{U R}}{d \tau^{U}}<0\right)$. The total U.S. firm-level sales will be lower $\left(\frac{d q^{U D}}{d \tau^{U}}+\frac{d q^{U R}}{d \tau^{U}}>0\right)$ because the direct effect (first term) is larger than the indirect effect (second term). With lower prices and firm-level sales, some firms will incur loss and exit the industry $\left(\frac{d N^{U}}{d \tau^{U}}>0\right)$. The reduction in the U.S. tariff will cause the price received by Chinese firms to increase. With higher exports and price, revenue will increase, causing more Chinese firms to enter $\left(\frac{d N^{C}}{d \tau^{U}}<0\right)$. Because it is more lucrative to export to the United States, China will divert its exports from the $\mathrm{EU}\left(\frac{d q^{C E}}{d \tau^{U}}>0\right)$ to the United States. Similar comparative static results and interpretations for productivity changes are also possible.

\subsection{Welfare Analysis}

In this section, we examine the impacts of a reduction in the U.S. tariff and productivity changes on U.S. and Chinese welfare. U.S. welfare comprises consumer surplus, producer surplus, and tariff revenues:

$$
W^{U S}=\underbrace{\left\{\int p^{U S}\left(Q^{U S}\right) d q^{U S}-p^{U S}\left(Q^{U S}\right) Q^{U S}\right\}}_{\mathrm{CS}}+\underbrace{N^{U} f^{U}}_{\mathrm{PS}}+\underbrace{\tau^{U} Q^{C U}}_{\mathrm{TR}},
$$

where total U.S. consumption is given by $Q^{U S}=Q^{U D}+Q^{C U}$. Consumer surplus (CS) is the area under the demand curve minus the expenditure. Firm-level producer surplus (PS) is total revenue minus variable cost, which is equal to total fixed cost given that profits are zero under free entry and exit. Then, industry-level producer surplus is the number of firms times fixed cost $\left(N^{U} f^{U}\right)$. Tariff revenue (TR) is per unit tariff times volume of imports.

Because consumer surplus is zero as there is no domestic consumption, Chinese welfare comprises only producer surplus:

$$
W^{C}=\underbrace{f^{C} N^{C}}_{\mathrm{PS}} .
$$

As in the case of U.S. producer surplus, the industry-level Chinese producer surplus is the number of firms times the fixed cost. 


\subsubsection{Welfare Analysis of Reduction in U.S. Tariff}

We totally differentiate equation (9) with respect to $\tau^{U}$ to determine the effects of a reduction in the U.S. tariff on U.S. welfare. The change in U.S. welfare is given by

$$
\frac{d W^{U S}}{d \tau^{U}}=\underbrace{-\frac{\partial p^{U S}}{\partial Q^{U S}} \frac{\partial Q^{U S}}{\partial \tau^{U}} Q^{U S}}_{\mathrm{CS}(-)}+\underbrace{f^{U} \frac{\partial N^{U}}{\partial \tau^{U}}}_{\mathrm{PS}(+)}+\underbrace{Q^{C U}\left(1+\frac{\partial Q^{C U}}{\partial \tau^{U}} \frac{\tau^{U}}{Q^{C U}}\right)}_{\mathrm{TR}(?)} .
$$

Chinese exports to the United States increase due to a reduction in the U.S. import tariff, resulting in a lower U.S. apple juice price. Due to this lower price, U.S. consumption rises, leading to a gain in consumer surplus. However, this lower price reduces profitability of U.S. apple juice processors, causing firms to exit and resulting in producer surplus loss. As imports increase, the change in tariff revenues could be positive or negative depending on whether the import demand curve is inelastic or elastic. Hence, the net welfare effect is ambiguous. However, because the United States is a net importing country, the gain in consumer surplus will most likely outweigh the losses in producer surplus and tariff revenues, if any, and U.S. welfare is likely to increase.

Because of higher exports, profitability of Chinese firms goes up, which results in entry of more firms into the Chinese apple processing industry. Thus, the change in Chinese welfare is

$$
\frac{d W^{C}}{d \tau^{U}}=\underbrace{f^{C} \frac{\partial N^{C}}{\partial \tau^{U}}}_{(-)}<0
$$

Because a reduction in U.S. tariff increases the number of firms in China, Chinese welfare will rise.

\subsubsection{Welfare Analysis of a Change in Chinese Productivity}

Due to economic reforms and foreign direct investment in food processing, Chinese firms acquire modern processing technology, leading to an increase in apple juice production. The effect of this increase in Chinese productivity on U.S. welfare is

$$
\frac{d W^{U S}}{d \omega^{C}}=\underbrace{-\frac{\partial p^{U S}}{\partial Q^{U S}} \frac{\partial Q^{U S}}{\partial \omega^{C}} Q^{U S}}_{\mathrm{CS}(+)}+\underbrace{f^{U} \frac{\partial N^{U}}{\partial \omega^{C}}}_{\mathrm{PS}(-)}+\underbrace{\tau^{U} \frac{\partial Q^{C U}}{\partial \omega^{C}}}_{\mathrm{TR}(+)} .
$$

With higher output, Chinese processors augment their exports to the United States, which lowers the U.S. apple juice price, leading to higher U.S. consumption and hence a gain in consumer surplus. As a result of imports from China, the sales of U.S. processors decline and their profits go down. This results in the exit of U.S. firms from the apple juice industry and causes producer surplus to decline. As imports rise, tariff revenue accrued to the U.S. government 
increases. Because the United States is a net importer, the net change in U.S. welfare is likely to be positive as the gain in consumer surplus and tariff revenues will offset the producer surplus loss.

With an increase in exports due to higher production, more firms enter the Chinese industry. The change in Chinese aggregate producer surplus due to a rise in productivity is given by

$$
\frac{\partial P S^{C}}{\partial \omega^{C}}=\underbrace{f^{C} \frac{\partial N^{C}}{\partial \omega^{C}}}_{(+)}>0 .
$$

We can also analyze the effect of tariff and productivity changes on U.S. apple juice importing countries' and EU welfare. However, due to space limitation, we are not reporting these analytical results, but we do provide the empirical results in the next section.

\section{Empirical Model and Analysis}

In this section, we derive the empirical model from the theoretical results, discuss data and sources, calibrate the parameters, and present simulation analysis and results.

\subsection{Empirical Model}

Because China exports to the United States and EU, and the United States sells in the domestic market and exports, the four supply relations for the empirical model are specified by rewriting the first-order conditions (equations 3-6) as

$$
\begin{gathered}
p^{U S}=\frac{\partial C^{U}(\cdot)}{\partial q^{U D}}+\psi^{U S} \xi^{U S} p^{U S} \\
p^{R}=\frac{\partial C^{U}(\cdot)}{\partial q^{U R}}+\psi^{U R} \xi^{U R} p^{R} \\
p^{U S}=\frac{\partial C^{C}(\cdot)}{\partial q^{C U}}+t^{U}+\psi^{C U} \xi^{U S} p^{U S}+\tau^{U} \\
p^{E}=\left(1+\tau^{E}\right)\left(\frac{\partial C^{C}(\cdot)}{\partial q^{E U}}+t^{E}\right)+\psi^{C E} \xi^{E U} p^{E},
\end{gathered}
$$

where $\psi^{i}$ is the firm-level conjectural elasticity (e.g., $\psi^{U S}=\frac{\partial\left(Q^{U D}+Q^{C U}\right)}{\partial q^{U D}} \frac{q^{U D}}{\left(Q^{U D}+Q^{C U}\right)}$ for a U.S. domestic firm), $\xi^{i}$ is the flexibility of demand in the $i$ th market (e.g., $\xi^{U S}=-\frac{\partial p^{U S}\left(Q^{U D}+Q^{C U}\right)}{\partial\left(Q^{U D}+Q^{C U}\right)} \frac{\left(Q^{U D}+Q^{C U}\right)}{p^{U S}\left(Q^{U D}+Q^{C U}\right)}$ for the U.S. market). The conjectural 
elasticities vary from zero to one. Markup $\left(\psi^{i} \xi^{U S} p^{U S}, i=U S, C U\right)$ depends on conjectural elasticities, demand flexibility, and price.

We specify demand and cost functions and consider the conjectural elasticities to derive supply relations. The marginal cost functions for U.S. and Chinese processors are given by

$$
\begin{gathered}
\frac{\partial C^{U D}}{\partial q^{U D}}=\frac{\partial C^{U}}{\partial q^{U R}}=\frac{\lambda_{0}^{U D}}{\omega^{U S}}+\lambda_{1}^{U D} \frac{\left(q^{U D}+q^{U R}\right)}{\left(\omega^{U S}\right)^{2}}, \\
\frac{\partial C^{C}}{\partial q^{C U}}=\frac{\partial C^{C}}{\partial q^{C E}}=\frac{\lambda_{0}^{C}}{\omega^{C}}+\lambda_{1}^{C} \frac{\left(q^{C U}+q^{C E}\right)}{\left(\omega^{C}\right)^{2}},
\end{gathered}
$$

where $\lambda \mathrm{s}$ are marginal cost coefficients and $\omega$ s are productivity parameters. Next, we specify the U.S. demand function

$$
p^{U S}=\mu_{0}^{U S}-\mu_{1}^{U S}\left(Q^{U D}+Q^{C U}\right),
$$

the demand for U.S. apple juice exports

$$
p^{R}=\mu_{0}^{R}-\mu_{1}^{R} Q^{U R},
$$

and the European demand for Chinese apple juice

$$
p^{E}\left(Q^{C E}\right)=\mu_{0}^{E}-\mu_{1}^{E} Q^{C E},
$$

where $\mu$ s are demand coefficients.

Using the redefined first-order conditions (equations 12-15), marginal cost functions (equations 16 and 17), demand functions (equations 18-20), and conjectural elasticities, the system of four supply relations and two zero-profit conditions can be written as follows:

Supply relations:

$$
\begin{gathered}
\pi_{q^{U D}}^{U S}=\mu_{0}^{U S}-\mu_{1}^{U S}\left(N^{U} q^{U D}+N^{C} q^{C U}\right)-\mu_{1}^{U S} q^{U D}-\frac{\lambda_{0}^{U D}}{\omega^{U S}}-\lambda_{1}^{U D} \frac{q^{U D}+q^{U R}}{\left(\omega^{U S}\right)^{2}}=0 \\
\pi_{q^{U R}}^{U S}=\mu_{0}^{R}-\mu_{1}^{R} N^{U} q^{U R}-\mu_{1}^{R} q^{U R}-\frac{\lambda_{0}^{U D}}{\omega^{U S}}-\lambda_{1}^{U D} \frac{q^{U D}+q^{U R}}{\left(\omega^{U S}\right)^{2}}=0 \\
\pi_{q^{C U}}^{C}=-\mu_{1}^{U S} q^{C U}+\left(\mu_{0}^{U S}-\mu_{1}^{U S}\left(N^{U} q^{U D}+N^{C} q^{C U}\right)-\tau^{U}\right)-\frac{\lambda_{0}^{C}}{\omega^{C}} \\
-\lambda_{1}^{C} \frac{q^{C U}+q^{C E}}{\left(\omega^{C}\right)^{2}}-t^{U}=0 \\
\pi_{q^{C E}}^{C}=\frac{1}{\left(1+\tau^{E}\right)}\left(\mu_{0}^{E}-\mu_{1}^{E} N^{C} q^{C E}-\mu_{1}^{E} q^{C E}\right)-\frac{\lambda_{0}^{C}}{\omega^{C}}-\lambda_{1}^{C} \frac{q^{C U}+q^{C E}}{\left(\omega^{C}\right)^{2}}-t^{E}=0
\end{gathered}
$$


Zero-profit equations:

$$
\begin{aligned}
\pi^{O U S}= & \left(\mu_{0}^{U S}-\mu_{1}^{U S}\left(N^{U} q^{U D}+N^{C} q^{C U}+Q^{U S O}\right)\right) q^{U D}+\left(\mu_{0}^{R}-\mu_{1}^{R} N^{U} q^{U R}\right) q^{U R} \\
& -\lambda_{0}^{U D} \frac{q^{U D}+q^{U R}}{\omega^{U S}}-\frac{\lambda_{1}^{U D}}{2}\left(\frac{q^{U D}+q^{U R}}{\omega^{U S}}\right)^{2}-f^{U}=0 \\
\pi^{O C}= & \left(\mu_{0}^{U S}-\mu_{1}^{U S}\left(N^{U} q^{U D}+N^{C} q^{C U}\right)-\tau^{U}\right) q^{C U}+\frac{\left(\mu_{0}^{E}-\mu_{1}^{E} N^{C} q^{C E}\right)}{\left(1+\tau^{E}\right)} q^{C E} \\
& -\lambda_{0}^{C} \frac{\left(q^{C U}+q^{C E}\right)}{\omega^{C}}-\frac{\lambda_{1}^{C}}{2}\left(\frac{q^{C U}+q^{C E}}{\omega^{C}}\right)^{2}-t^{U} q^{C U}-t^{E} q^{C E}-f^{C}=0 .
\end{aligned}
$$

Using the previous system of six equations, we solve for six unknowns $\left(q^{U D}\right.$, $q^{U R}, q^{C U}, q^{C E}, N^{U}$, and $N^{C}$ ) simultaneously using simulation analysis. Once we solve for these six endogenous variables, we can obtain the aggregate quantity by multiplying the firm-level quantity times the number of firms and prices by substituting the aggregate quantities into the demand functions.

\subsection{Calibration and Data}

For the simulation analysis, coefficients of the supply relations and demand functions are parameterized using prices, quantities, tariff, and transport cost data and demand, supply, and conjectural elasticities. For the calibration, all data are averaged over the five year period: 2005-2009. We assume Cournot competition at the industry level, which implies that $\frac{\partial\left(Q^{U D}+Q^{C U}\right)}{\partial Q^{i}}=1$, and thus the conjectural elasticities are given by market shares $\psi^{i}=\frac{Q^{i}}{Q^{U D}+Q^{C U}}$.

U.S. apple juice production, total consumption, import, and export data were collected from U.S. Department of Agriculture, National Agricultural Statistics Service (2014) and the U.S. Census Bureau (2014). The United States exports apple juice to Canada, Mexico, and Japan. Chinese exports to the United States and EU were collected from FAOSTAT (Food and Agriculture Organization of the United Nations, 2014). ${ }^{2}$ U.S. price data for apple juice concentrate were obtained from the Apple Processors Association (2014). The prices in the EU and U.S. apple juice importing countries are calculated as the unit values (i.e., value of imports divided by quantity of imports). The U.S. antidumping duty on China was imposed in 1999 at 4.9 cents per gallon (WTO, 2014). The transportation cost data were calculated as the difference between free on board values and cost, freight, and insurance values of Chinese exports to the United States and the EU.

The conjectural elasticities for U.S. and Chinese firms' sales in the United States are calibrated based on average market shares and are 0.22 and 0.71 ,

2 The data for apple juice concentrate were converted from tons to SSE gallons. 
Table 1. Impacts of Tariff Elimination and Productivity Changes

\begin{tabular}{lcr}
\hline \hline & $\begin{array}{r}50 \% \text { Reduction } \\
\text { in } \tau^{U}\end{array}$ & $\begin{array}{r}10 \% \text { Increase } \\
\text { in } \omega^{C}\end{array}$ \\
Variables & -19.00 & -2.53 \\
\hline U.S. price $p^{U}$ (\% change) & -19.48 & -5.67 \\
European Union (EU) price $p^{E}$ (\% change) & -32.22 & -4.65 \\
U.S. firm-level domestic sales $q^{U D}(\%$ change) & 31.95 & 5.87 \\
U.S. firm-level exports $q^{U R}(\%$ change) & 9.99 & 3.52 \\
Chinese firm-level exports to U.S. $q^{C U}(\%$ change) & -13.20 & -0.24 \\
Chinese firm-level exports to EU $q^{C E}(\%$ change) & -61.71 & -14.48 \\
U.S. aggregate domestic sales $Q^{U D}(\%$ change) & -25.46 & -5.05 \\
U.S. aggregate exports $Q^{U R}(\%$ change) & 42.78 & 7.60 \\
Chinese aggregate exports to U.S. $Q^{C U}(\%$ change) & 12.66 & 3.69 \\
Chinese aggregate exports to EU $Q^{C E}(\%$ change) & -43.51 & -10.31 \\
Number of firms in U.S. $N^{U}(\%$ change) & 29.80 & 3.94 \\
Number of firms in China $N^{C}(\%$ change) & 53.60 & 17.30 \\
\hline Change in total U.S. welfare $(\$$ m) & 96.32 & 12.05 \\
Change in U.S. consumer surplus $(\$ \mathrm{~m})$ & -30.79 & -7.30 \\
Change in U.S. producer surplus $(\$ \mathrm{~m})$ & -11.93 & 12.55 \\
Change in tariff revenue $(\$ \mathrm{~m})$ & 45.77 & 6.05 \\
Change in Chinese welfare (producer surplus) $(\$ \mathrm{~m})$ & \\
\hline \hline
\end{tabular}

respectively. The supply flexibilities of U.S. domestic supply and Chinese exports to United States are assumed at 1.00. Based on the conjectural elasticities, supply flexibilities, and price and quantity data, the slope and intercept parameters for the marginal cost function for U.S. processors are calculated as 0.004 and 0.07 , and Chinese processors as 0.0006 and 0.06 .

Mekonnen and Fonsah (2011) estimated the U.S. import demand elasticity of apple juice as -0.63 (flexibility of -1.58 ). Similarly Andreyeva, Long, and Brownell (2010) found that the demand elasticity for fruit juices is more elastic and ranges from -0.70 to -0.82 (flexibility of -1.43 to -1.23 ). Using these elasticity estimates as a basis, and along with price and quantity data, we compute the intercept and slope parameters of U.S. demand function as 1.99 and -0.002 , respectively. Similarly, we construct demand function for U.S. exports with intercept 2.46 and slope -0.047 , and EU demand function with intercept 2.48 and slope -0.01 .

\subsection{Simulation}

We analyze the impact of U.S. tariff reduction and an increase in Chinese productivity relative to U.S. productivity on prices, production, trade, market structure, and welfare through simulation analysis. Table 1 reports the simulation results.

U.S. Tariff Reduction: For this analysis, we run two scenarios: baseline with the U.S. tariff in place and an alternate scenario with a $50 \%$ reduction of the U.S. tariff. We compare the results of the alternate scenario with the baseline 
scenario to analyze the impacts of this trade policy. Removal of the tariff by the United States causes China to increase its exports to the United States. With the increase in imports, U.S. apple juice price declines by $19.00 \%$. Due to cheaper imports, the profitability of U.S. processors is affected, U.S. firm-level sales in the United States fall by $32.22 \%$, and the number of firms declines by $43.51 \%$. As U.S. firms face competition in the domestic market, they divert their sales to foreign countries. U.S. firm-level exports increase by $31.95 \%$. However, the aggregate U.S. exports decline by $25.60 \%$ because of the fall in the number of firms. As a result, the sum of domestic and export sales falls. With a lower price, consumption in the United States increases, and hence consumer surplus goes up \$96.32 million. Because the number of U.S. firms declines, the total producer surplus loss is $\$ 30.79$ million. Due to reduction of the tariff, tariff revenues fall by $\$ 11.93$ million. This results in a net welfare gain of $\$ 53.60$ million.

As China finds it more profitable to sell in the U.S. market, Chinese firms reallocate their exports from the EU to the United States. In addition, the number of Chinese firms goes up by $29.80 \%$. Consequently, Chinese aggregate apple juice exports to the United States increase by $42.78 \%$. Even though firm-level exports to the EU decline, the aggregate exports to the EU rise by $12.66 \%$. As more firms enter Chinese apple juice production, the aggregate producer surplus in China rises by $\$ 45.77$ million.

Increase in Chinese Productivity: For this analysis, we consider two simulation scenarios: baseline with no changes in productivity and an alternate scenario with a $10 \%$ increase in Chinese processors' productivity relative to U.S. processors' productivity. We compare the results of the alternate scenario with the baseline scenario to analyze the impact of a Chinese productivity increase. China increases its apple juice production and hence exports more to the United States. Chinese firm-level and aggregate exports to the United States rise by $3.52 \%$ and $7.60 \%$, respectively. Because of the higher exports from China, the price of apple juice in the United States decreases by $2.53 \%$, which reduces the profit of U.S. processors. This affects the sales of domestic processors in the United States, and firm-level supply declines by $4.65 \%$. As a result, U.S. aggregate domestic sales fall by $14.48 \%$, which causes the number of U.S. firms to decline by $10.31 \%$. Due to the loss in market share in the United States, U.S. firms augment their exports by $5.87 \%$. However, aggregate exports fall by $5.05 \%$ because of the lower number of U.S. firms $(10.31 \%)$.

Consumption in the United States increases as a result of the lower price, leading to a gain in consumer surplus of $\$ 12.05$ million. Because of the additional Chinese exports, U.S. producers lose $\$ 7.30$ million. With higher imports, tariff revenues increase by $\$ 12.55$ million. Because the United States experiences a gain in both consumer surplus and tariff revenues, the total welfare gain is $\$ 17.30$ million. 
Table 2. Sensitivity Analysis for U.S. and European Union (EU) Demand Elasticities

\begin{tabular}{|c|c|c|c|c|}
\hline \multirow[b]{2}{*}{ Variables } & \multicolumn{2}{|c|}{$\begin{array}{c}20 \% \text { Increase in } \\
\text { Demand Elasticities }\end{array}$} & \multicolumn{2}{|c|}{$\begin{array}{c}20 \% \text { Decrease in } \\
\text { Demand Elasticities }\end{array}$} \\
\hline & $\tau^{U}$ & $\omega^{C}$ & $\tau^{U}$ & $\omega^{C}$ \\
\hline U.S. price $p^{U}(\%$ change $)$ & -18.99 & -3.64 & -18.87 & -0.50 \\
\hline EU price $p^{E}$ (\% change) & -17.25 & -7.13 & -22.51 & -1.46 \\
\hline U.S. firm-level domestic sales $q^{U D}(\%$ change $)$ & -32.71 & -6.75 & -31.24 & -0.90 \\
\hline U.S. firm-level exports $q^{U R}(\%$ change $)$ & 31.74 & 8.13 & 32.06 & 1.23 \\
\hline Chinese firm-level exports to U.S. $q^{C U}$ (\% change) & 11.02 & 5.91 & 8.93 & 0.42 \\
\hline Chinese firm-level exports to EU $q^{C E}$ (\% change) & -14.61 & 0.29 & -11.73 & -0.29 \\
\hline U.S. aggregate domestic sales $Q^{U D}(\%$ change $)$ & -61.47 & -19.64 & -61.78 & -3.18 \\
\hline U.S. aggregate exports $Q^{U R}(\%$ change $)$ & -24.57 & -6.82 & -26.59 & -1.10 \\
\hline Chinese aggregate exports to U.S. $Q^{C U}$ (\% change) & 47.50 & 11.48 & 37.85 & 1.47 \\
\hline Chinese aggregate exports to EU $Q^{C E}$ (\% change) & 13.45 & 5.57 & 11.71 & 0.76 \\
\hline Number of firms in U.S. $N^{U}$ (\% change) & -42.74 & -13.82 & -44.41 & -2.30 \\
\hline Number of firms in China $N^{C}$ (\% change) & 32.86 & 5.26 & 26.55 & 1.05 \\
\hline Change in total U.S. welfare $(\$ \mathrm{~m})$ & 63.94 & 26.84 & 41.66 & 3.09 \\
\hline Change in U.S. consumer surplus (\$ $\mathrm{m})$ & 97.63 & 17.43 & 94.24 & 2.35 \\
\hline Change in U.S. producer surplus ( $\$ \mathrm{~m})$ & -29.56 & -9.56 & -32.51 & -1.69 \\
\hline Change in tariff revenue $(\$ \mathrm{~m})$ & -4.13 & 18.97 & -20.07 & 2.43 \\
\hline Change in Chinese welfare (producer surplus) (\$ m) & 36.80 & 5.89 & 57.33 & 2.26 \\
\hline
\end{tabular}

Because Chinese processors find it profitable to produce and export, the total exports to the United States rise, and new firms also enter the industry $(3.94 \%)$. Because of the productivity increases, Chinese total exports to the EU also rise by $3.69 \%$. The aggregate producer surplus in China increases by $\$ 6.05$ million. These results corroborate the comparative static theoretical results of the welfare analysis.

Sensitivity Analysis: Table 2 reports the results for a $20 \%$ increase and a $20 \%$ decrease in the demand elasticities for both tariff and productivity simulation scenarios. The results show that changes in demand elasticities do not alter the simulation results significantly. For instance, changes in the U.S. price range from $-18.87 \%$ to $-18.99 \%$ in the tariff scenarios. U.S. firm-level domestic sales also range from $-31.24 \%$ to $-32.71 \%$. For the productivity scenarios, the results are also fairly stable. For instance, the U.S. price change ranges from $-0.50 \%$ to $-3.64 \%$. In general, the lower demand elasticity values slightly dampen the impacts.

\section{Conclusions}

The United States is one of the leading consumers of apple juice in the world accounting for about $36 \%$ of total world apple juice imports in 2009 . In recent years, the U.S. apple juice industry has consolidated its production, and fewer processors produce apple juice. Due to government support and foreign direct 
investments, the apple juice industry in China has experienced rapid growth, resulting in a geographic shift in the concentration of the apple juice industry. This has led to oligopolistic competition with a few firms exerting market power over sales and prices. The United States is a leading importer of apple juice from China and has imposed an antidumping duty on apple juice imports from China.

We formulate a strategic trade model of the U.S. and Chinese apple juice markets based on NTT. We endogenize firm entry and exit by incorporating zeroprofit conditions for U.S. and Chinese apple juice processors. We theoretically analyze the effects of changes in the U.S. tariff and a productivity shock on the apple juice market. From the theoretical results, we derive an empirical model for U.S. demand, U.S. domestic and export supply relations, and Chinese export supply relations. Using past studies, we calibrate the parameters of demand functions and supply relations and calculate U.S. demand flexibilities and conjectural elasticities of U.S. and Chinese processors. We also incorporate two zero-profit conditions to endogenize the number of firms. Using the system of six simultaneous equations, we solve for six endogenous variables: U.S. domestic supply, U.S. export supply, Chinese exports to the United States, Chinese exports to the EU, and the number of U.S. processors and Chinese processors.

We conduct two simulation analyses: U.S. tariff reduction and Chinese productivity increase. The results show that reduction of the U.S. tariff leads to more Chinese exports to the United States, resulting in a decrease in the U.S. price, profitability, supply, and firm exits. U.S. tariff removal causes more firms to enter in China and an increase in production. Higher Chinese apple juice productivity results in entry of firms, production, and exports to the United States, which augments both consumer surplus and tariff revenues but lowers producer surplus. However, because the United States is a net importer, the net welfare rises. Productivity improvements benefit Chinese firms, which increases their exports and market share in the United States.

Given the free-trade agreements and negotiations such as the Doha Round agreement, U.S. apple juice processors need to increase their productivity. Similarly, U.S. apple growers should also enhance their productivity to increase apple production because apples are the single most important intermediate input in juice production. Also, U.S. apple juice processors should invest in advanced processing technologies to increase their competitiveness and hence profitability.

\section{References}

Andreyeva, T., M.W. Long, and K.D. Brownell. "The Impact of Food Prices on Consumption: A Systematic Review of Research on the Price Elasticity of Demand for Food". American Journal of Public Health 100,2 (2010):216-22.

Apple Processors Association. Internet site: http://www.appleprocessors.org/ (Accessed June 2014).

Ayumu, T. What is "New” New Trade Theory? Tokyo, Japan: Research Institute of Economy, Trade and Industry, Technical Report, 2010. 
Brander, J., and P. Krugman. “A 'Reciprocal Dumping' Model of International Trade." Journal of International Economics 15,3-4(1983):313-21.

Devadoss, S., W. Ridley, and P. Sridharan. "Trade Policies in World Apple and Juice Markets." Poster presented at the Agricultural and Applied Economics Association Annual Meeting, Seattle, WA, August 12-14, 2012.

Dixit, A., and V. Norman. Theory of International Trade: A Dual, General Equilibrium Approach. Cambridge: Cambridge University Press (1980).

Etro, F. "Optimal trade policy under endogenous foreign entry". Economic Record, 90,290(2014):282-300.

Fonsah, E.G., and A. Muhammad. "The Demand for Imported Apple Juice in the United States". Journal of Food Distribution Research 39,1(2008), 57-61.

Food and Agriculture Organization of the United Nations. FAOSTAT. Internet site: http://faostat.fao.org/default.aspx (Accessed 2014).

Gale, F., S. Huang, and Y. Gu. Investment in Processing Industry Turns Chinese Apples into Juice Exports. Washington, DC: U.S. Department of Agriculture, Economic Research Service, Outlook Report FTS-344-01 (2010).

Helpman, E. "International Trade in the Presence of Product Differentiation, Economies of Scale and Monopolistic Competition: A Chamberlin-Heckscher-Ohlin Approach.” Journal of International Economics 11,3(1981):305-40.

Horstmann, I.J., and J.R. Markusen. "Up the Average Cost Curve: Inefficient Entry and the New Protectionism." Journal of International Economics 20,3-4(1986): 225-47.

Krugman, P. “Scale Economies, Product Differentiation, and the Pattern of Trade." American Economic Review 70,5(1980):950-59.

—. "Does the New Trade Theory Require a New Trade Policy?" The World Economy 15,4(1992):423-42.

Krugman, P.R. "Increasing Returns, Monopolistic Competition, and International Trade." Journal of International Economics 9,4(1979):469-79.

Lahiri, S., and Y. Ono "Foreign Direct Investment, Local Content Requirement, and Profit Taxation.” Economic Journal 108,447(1998):444-57.

Luckstead, J., S. Devadoss, and R.C. Mittelhammer. "Apple Export Competition between the United States and China in the Association of Southeast Asian Nations.” Journal of Agricultural and Applied Economics 46,4(2014a):635-47.

Luckstead, J., S. Devadoss, and R.C. Mittelhammer. "Imperfect Competition between Florida and São Paulo (Brazil) Orange Juice Producers in the U.S. and European Markets.” Journal of Agricultural and Resource Economics 40,1(2015):164-78.

Luckstead, J., S. Devadoss, and R.C. Mittelhammer. "US and Chinese Strategic Trade Policies and Product Differentiation in the ASEAN Apple Market." International Economic Journal 28,4(2014b):613-37.

Markusen, J., and F. Stähler "Endogenous Market Structure and Foreign Market Entry." Review of World Economics 147,2(2011):195-215.

Markusen, J.R., and A.J. Venables. "Trade Policy with Increasing Returns and Imperfect Competition: Contradictory Results from Competing Assumptions." Journal of International Economics 24,3-4(1988):299-316.

Mekonnen, D.K., and E.G. Fonsah. "Demand Estimation for US Apple Juice Imports: A Restricted Source Differentiated AIDS Model." Paper presented at the Southern Agricultural Economics Association Annual Meeting, Corpus Christi, TX, February, $5-8,2011$. 
Melitz, M.J. “The Impact of Trade on Intra-Industry Reallocations and Aggregate Industry Productivity." Econometrica 71,6(2003):1695-725.

Melitz, M.J., and G.I. Ottaviano. "Market Size, Trade, and Productivity." Review of Economic Studies 75,1(2008):295-316.

Rowles, K. "Processed Apple Product Marketing Analysis: Apple Juice \& Cider." Staff paper SP 2001-01, Ithaca, NY: Cornell University, Department of Agricultural, Resource, and Managerial Economics (2001).

United Nations. UN Comtrade Database. Internet site: http://comtrade.un.org/data/. (Accessed 2014).

U.S. Census Bureau. "Foreign Trade.” Internet site: http://www.census.gov/foreign-trade (Accessed 2014).

U.S. Department of Agriculture, National Agricultural Statistics Service. "Quick Stats." Internet site: http://www.nass.usda.gov (Accessed 2014).

van Voorthuizen, H., S.-Y. Cho, T. Schotzko, and R. Mittelhammer. "The Apple Juice Concentrate Anti-Dumping Case against China: An Estimate of Change in Washington's Revenues." Journal of Food Distribution Research 32,1(2001): 188-96.

Venables, A.J. "Trade and Trade Policy with Imperfect Competition: The Case of Identical Products and Free Entry." Journal of International Economics 19,1(1985): 1-19.

World Trade Organization. "Tariff Analysis Online." Internet site: https://tao.wto.org/ (Accessed 2014).

Zai-Long, L. "Deciduous Fruit Production in China." Deciduous Fruit Production in Asia and the Pacific. M.K. Papademetriou and E.M. Herath, eds. Bangkok, Thailand: Food and Agriculture Organization of the United Nations, Regional Office for Asia and the Pacific, 1999. 